Леонид Ф. Кацис

Институт филологии и истории

Российский государственный гуманитарный

университет

batya-94@mail.ru
УДК 821.161.1.09"19"

https://doi.org/10.18485/slavistika.2020.24.1.4

Оригинални научни рад

примљено 03.04.2020.

прихваћено за штампу 21.05.2020.

\title{
В. ПАРНАХ, И. ЗДАНЕВИЧ И «ПАЛАТА ПОЭТОВ»: МЕЖДУ ЛИТЕРАТУРОЙ, НКВД, “ЕГИПЕТСКОЙ МАРКОЙ» И «ШУМОМ ВРЕМЕНИ» О.Э. МАНДЕЛЬШТАМА
}

Настоящая работа посвящена анализу прозаических текстов трех русских поэтов О.Э. Мандельштама («Шум времени», «Египетская марка»), Ильязда («Философия») и В.Я. Парнаха «Пансион Мобэр»). На основе предыдущих исследований автора, посвященных сочинениям Ильязда и Парнаха и связанных со церковными спорами в кругах русской эмиграции, автор включает в этот контекст и «Египетскую марку» О.Э. Мандельштама, где в имени главного героя Парнока легко узнается имя В.Я. Парнаха. В свою очередь, О.Э. Мандельштам имел биографические связи с обоими героями статьи, а В. Парнах и Ильязд основали в Париже «Палату поэтов». И В.Я. Парнах, и Ильязд включили в свои произведения сведения, не доступные исследователям предыдущих десятилетий и становящиеся известными лишь сегодня. Это и материалы «Братства Святой Софии», и межцерковные споры в Париже 1920-х гг. вокруг просоветских «обновленцев», Русской Православной Церкви и круга митрополита Евлогия, тяготевшего к Константинопольскому патриархату. Представленный материал позволяет автору поставить проблему: для чего и в каком контексте О.Э. Мандельштам сделал главным героем «Египетской марки» Парнока, явно напоминавшего о В.Я. Парнахе, который в это время находился в Париже в неясном статусе то ли эмигранта, то ли просоветского апатрида. Наконец, возможно ли найти связи между деятельностью советской разведки в Париже, особенно Е. Феррари, тесно включенной в авангардные круги Москвы, Берлина и Парижа, и авторами здесь упомянутыми.

Ключевые слова: Русская эмиграция, Париж, «Шум времени», «Египетская марка», «Пансион Мобэр», НКВД.

This work is dedicated to the analysis of the prose texts of three Russian poets: O.E. Mandelstam ("The Noise of Time", "The Egyptian Stamp"), Ilyazd ("Philosophy") and V.Ya. Parnach "Pension Mobar"). Following on from the author's previous studies on the writings of Ilyazd and Parnakh related to church discussions in Russian émigré circles, in this paper the author includes O.E. Mandelstam, although he spent this period in Soviet Russia. A reader can easily recognize the name of V. Ya. Parnach in the name of the main character of "The Egyptian Stamp", Valentin Parnok. At the same time, O.E. Mandelstam had biographical ties with the other two writers. On the other hand, both Parnach and Ilyazd founded the "Chamber of Poets" in Paris. Both of them included in their works information not previously available to researchers and which has only recently become known. This includes documents of the "Brotherhood of Saint Sophia" and inter-church disputes that took place in Paris in the 1920s. Amongst pro-Soviet "Renovationists" ("obnovlentzy"), the Russian Orthodox Church headed by Metropolitan Sergey and the circle of Metropolitan Eulogius, gravitated towards the Patriarchate of Constantinople. The material allows the author to raise the following question: why did O.E. Mandelstam give the main character of "The Egyptian Stamp" the name Parnok, a name clearly reminiscent of V. Ya. Parnach, who at that time was in Paris, living with an unclear status of either emigrant or pro-Soviet stateless person? Finally, the question arises whether it possible to find any ties between the activity of the Soviet Intelligence in Paris, specifically E. Ferrary, who was closely connected to the avant-garde in Moscow, Berlin and Paris, and the figures mentioned here.

Keywords: Russian emigration, Paris, "The Noise of Time", "Egyptian Stamp", "Pension Mobare", NKVD. 
Предлагаемая работа посвящена одному специфическому способу работы с литературными текстами совершенно особого типа. Речь идет о произведениях, созданных - один в эмиграции (около 1930), другой - то ли в эмиграции, то ли в СССР (не ранее 1934 г.), но оба они посвящены темам, связанным с таким не самым частым в художественной литературе явлением, как борьба советских властей с эмигрантскими религиозными объединениями за рубежом. Причем, эти произведения, по крайней мере их авторами, планировались для публикации в СССР сразу после их создания, и там они никогда не вышли в свет, равно как не вышли они в свет при жизни их авторов и после их смерти в эпоху существования СССР.

Мы имеем в виду два сочинения двух русских поэтов - близкого к «Аполлону» и «Цеху поэтов», а впоследствии авангардиста В.Я. Парнаха и поэта-заумника, члена тифлисского «41о» Ильязда (Ильи Зданевича).

Первый написал мемуарную книгу «Пансион Мобэр» (Парнах 2005), охватывающую период от его еврейского детства в Российской империи времен погромов и дела Бейлиса через пребывание в Палестине, Египте, Париже, затем - возврата в Москву, вновь поездки в Париж и вплоть до окончательного возвращения в страну победившего социализма (Кацис, Брусиловская 2018б).

Второй создал обширный и совсем не заумный роман «Философия» (Зданевич 2008), в котором полуоткрыто затрагивались проблемы жизни и деятельности достаточно закрытого «Братства Св. Софии», работавшего в Париже, Праге, Белграде и т.д., однако начавшего свою деятельность еще в царской России, а продолжившего его размышлениями о России, Константинополе и проливах во время т.н. «кутепии», т.е. эпохи существования отступившей из Крыма Белой Армии в Галлиполийских лагерях, наконец, продолжившего свои размышления уже в столицах эмиграции (Кацис 2014).

Совмещение в одной работе этих двух сочинений мотивируется не только тем, что оба поэта стали основателями «Палаты поэтов» в Париже, но и тем, что Братство Св. Софии находилось на острие борьбы с советскими попытками внедрения в эмигрантскую ситуацию просоветской обновленческой церкви. Трудность ситуации заключалась в том, что и отколовшийся от РПЦ митрополит Евлогий, перешел в Константинопольскую иерархию, и, одновременно, Фанар вполне открыто поддерживал советское обновленчество (Свящ. Мазырин А., Костриков А. 2017)

До недавних пор понять, о чем идет речь, применительно к «Пансиону Мобэр», было очень трудно. Казалось, что этот текст не связан с конкретной политической реальностью и, тем более, открытой политической борьбой, тем более с разведкой вообще. Еще больше сомнений вызывала и сама фигура В.Я. Парнаха, которого молва напрямую связывала с несчастным и ничтожным «маленьким человеком» (и даже «человечком») Парноком из «Египетской марки» Осипа Мандельштама (Кацис 2018а).

Между тем, наши изыскания показали, что в сердцевине «Пансиона Мобэр», в самом неожиданном месте обсуждаются как раз эти материи.

В том самом пансионе, который, разумеется, невозможно найти в Париже, даже если там есть район с таким названием, появляется персонаж, которого не смогли опознать наши предшественники. Это некий «священник Спасский», 
кавалер ордена Почетного легиона и Георгиевского креста, поднявший полк в атаку и потерявший при этом руку.

Им оказался о. Сергей Соколовский, очень значимая фигура не только в истории обновленчества, но и истории попыток советского проникновения в Русскую Зарубежную Церковь (Кацис 218в).

Само по себе это все не имело бы большого значения, если бы якобы прототип бедного Парнока «Египетской марки» в реальности не был очень идейным евреем, для которого, в отличие от формально крестившегося путем покупки соответствующего методистского свидетельства, О.Э. Мандельштама, вопрос смены веры да еще в далеком от семитофильства кругу был вообще невозможен.

Более того, автор «Пансиона Мобэр» даже специально подчеркивает антисемитизм Соколовского.

А фигура он очень заметная, попавшая и в мемуары митрополита Евлогия, и в другие исторические документы.

Учитывая, что Соколовский очень важная фигура во всей этой игре, приведем сведения о нем из специального православного источника: «1 марта 1915 году 7-й Финляндский стрелковый полк готовился к наступлению на австрийском фронте, перед началом которого предстояло разрушить проволочные заграждения на позициях противника. Несколько безуспешных попыток закончились большими потерями, после чего отец Сергий вызвался организовать вылазку, которая увенчалась успехом. В том бою был ранен ружейной пулей в бедро. Узнав о его геройском поведении в бою, протопресвитер Георгий Шавельский на рапорте написал: «...горжусь чудной работой о. Соколовского...»

В 1916 году по представлению протопресвитера Георгия Шавельского был назначен благочинным всех церквей особых специальных бригад, отправлявшихся на фронт во Францию. На фронте служил военным священником 6-го русского полка, прибывшего во Францию в том же году в составе экспедиционного корпуса для военных действий против Германии. Во время военных действий во Франции проявил большую храбрость, за что был прозван французами «легендарным священником». Он был ещё дважды ранен, во второй раз - с потерею кисти правой руки. Это произошло на театре военных действий под Оберни в Шампани 16 декабря того же года». https://drevo-info.ru/ articles/28148.html

Дальнейшая судьба его была связана и с русским православием, и с организациями помощи ветеранам и жертвам войны, и т.д. Однако по воспоминаниям митрополита Евлогия (Георгиевского): «Поначалу пользовался покровительством бывшего министра иностранных дел императорской России С. Д. Сазонова - по просьбе последнего приходской совет Парижской АлександроНевской церкви назначил ему пенсию, ограничив её получение 1924 годом. При этом о. Сергий стал всё острее конфликтовать с приходом. В 1921 году, по прибытии в Париж нового митрополита Евлогия (Георгиевского), сразу отправился к нему для выражения своего недовольства. По воспоминаниям митрополита:

«На другой день по моём приезде пришел ко мне однорукий протоиерей Соколовский с крестом на Георгиевской ленте; [...] О. Соколовский обратился ко мне с жалобами на невнимание к нему, герою войны, Приходского совета, 
который не соглашался провести его в штатные священники при АлександроНевской церкви, тогда как бывший Министр иностранных дел Сазонов этого желает... Резкий, вызывающий тон его речи, острый взгляд глаз заставили меня быть осторожным; я отвечал уклончиво. Он возил меня к некоему Брянчанинову на какое-то собрание приходской оппозиции, где дебатировались церковные вопросы в духе Всероссийского Церковного Собора и клеймился старый, затхлый дух, который якобы характеризует приходскую жизнь Парижской церкви. Потом я понял, что священник Соколовский хотел меня поссорить с Приходским советом и причтом, которых он вооружал против себя своим желчным характером и неосновательными претензиями» (Евлогий).

Дух Всероссийского церковного собора подразумевал реформы в Церкви. Более того, одним из лидеров этого был «митрополит» Александр Введенский, который, как и Соколовский побывал военным священником: «В 1913 г., только что закончив университет, Введенский экстерном сдал экзамен за курс Петербургской духовной академии. Перед самой войной, в июне 1914 г., его рукоположили в пресвитерский сан и назначили священником в один из полков, стоявших под Гродно. Два следующих года он прослужил полковым священником, а в 1916 г. был переведен в Петроград в аристократическую церковь Николаевского кавалерийского училища. В 1919 г. ее закрыли. Введенский остался без прихода и в течение нескольких месяцев перебивался случайными заработками (одно время даже торговал газетами). (...) Наконец Введенскому удалось добиться места настоятеля церкви Захария и Елизаветы на Захарьевской улице в Петрограде. В 1921 г. он был возведен в сан протоирея» https://domknig.com/read_105809-307.

И вот отсюда началась его карьера активного сотрудничества с Советской властью.

Мы не будем сейчас разбираться во всем этом, ясно только, что переход о. Сергея Соколовского в откровенно советскую церковь не мог не привести к разрыву с зарубежниками. В итоге, священник Соколовский оказался не только у советских обновленцев, но и стал выполнять очень деликатные вполне внутрицерковные поручения. И в этом бы не было ничего страшного, если бы подобная фигура не стала в центр парижской части повествования «Пансиона Мобэр». Отсюда мы могли узнать то, что герой-повествователь прозы Парнаха не только знал о том, что Соколовский сотрудничал с банком, принадлежавшем советскому посольству, но этот же повествователь встретил Соколовского уже в Москве в Большом театре вместе еще с несколькими знакомыми по Парижу.

Эти сведения вполне могут иметь отношение к реальности. По крайней мере в 1932 г. Соколовский был в Москве и обращался в РПЦ за восстановлением своего священнического сана, чего и добился.

Обстоятельства были таковы: «В том же 1925 году Соколовский основал «Общество взаимопомощи инвалидов специальных русских полков, посланных на Французский фронт» (позднее: «Союз инвалидов - граждан СССР») и стал работать в подведомственном советскому правительству Банке Северных Стран. 
В конечном итоге усилия «парижских обновленцев», направленные на захват церковной собственности Православной Российской Церкви во Франции - общая стоимость которой тогда оценивалась около 100 млн фр. франков - не увенчались успехом. 5 апреля 1928 года Первая палата гражданского трибунала департамента Сены отменила постановление от 22 октября 1924 года об аресте русской церковной собственности. Недовольный Соколовский обвинил посла СССР во Франции Довгалевского в пассивности, и представитель советской стороны подал кассационную жалобу, но в апреле 1930 года кассация была отклонена.

В 1930 за советскую пропаганду был выслан французскими властями, вернулся в СССР».

Конец его был тоже не очень обычен. Незадолго до своей смерти присоединился к Римо-католической церкви и стал служить по восточному обряду.

Скончался в 1934 году в Литве, сообщает о нем Википедия.

Впрочем, это нас сейчас не интересует. Для нас куда важнее, что тот банк, в котором работал скромный священник, - Коммерческий банк для Северной Европы (La Banque commerciale pour l'Europe du Nord) - т.н. «навашинский», по имени его руководителя, то ли резидента, то ли двойного агента по заданию ГПУ, то ли перебежчика, впрочем, в итоге ГПУ же и убитого в 1937 г., был местом постоянных и очень кровавых событий. Их можно найти в сводках эмигрантской печати в содержательной книге В. Гениса по указателю (Генис).

Таким образом, свободная и меланхоличная, с виду, проза Парнаха скрывает под собой очень неоднозначные события, мало вяжущиеся с образом «маленького человека». Более того, в истории парижской эмиграции Парнах не попал даже в библиографию, хотя соответствующих стихов, рецензий и книг он издал более, чем достаточно. Однако составитель библиографии Л. Ливак резонно отметил, что Парнах ездил туда-сюда из Парижа в Москву, поэтому библиография Парнаха в его англоязычные парижские библиографии не входит и канадский исследователь включил ее только в отдельную историю парижского авангарда (Ливак, Устинов), не обязательно связанную с «полноценными» эмигрантами.

С 1922 по 1924 г. Парнах жил в тесном контакте с Мандельштамами О.Э. и Н.Я., а с 1925 по 1931 год провел в Париже до возвращения в Москву. Попробуем сопоставить эти даты 1919-1922 с перерывом на 1922-24 и далее с 1925 по 1931 с событиями в жизни о. Соколовского и в истории «навашинского» банка. Тем более, что в «Пасионе Мобэр» мы можем узнать о них следующее:

«Новый жилец ступал неслышным кошачьи шагом, косил и никогда не смотрел людям прямо в глаза. Его взгляд, казалось, хотел укрыться за очками. Но отличала его другая особенность: правая рука в черной перчатке всегда неподвижно висела; время от времени он поддерживал ее левой. Иногда он приподнимал неподвижную руку и, показывая ее русским собеседникам, объяснял:

- Мне ее подарили французские жиды!

Это был русский священник отец Спасский, прибывший во Францию, как и Дарьин муж, с экспедиционным корпусом русских войск. 
Если верить рассказам Дарьи (а это можно было узнать и из газет. - Л.К.), в сражении отец Спасский занял место убитого командира и с крестом в руке повел полк в атаку. Он был ранен, и ему ампутировали руку до локтя (16.12.1916). Месяцами он ходатайствовал перед русским посольством о выдаче ему пособия (Пенсия от бывшего правительства адмирала Колчака с 1919 по 1921) на покупку протеза. Но царские канцеляристы не двинули пальцем даже ради этого «истинно русского» служителя церкви и трона. Тщетно обращался он в разные благотворительные патриотические общества и учреждения (приходской совет Парижской Александро-Невской церкви назначил ему пенсию, ограничив её получение 1924 годом, однако Поначалу пользовался покровительством бывшего министра иностранных дел императорской России С. Д. Сазонова - по просьбе последнего приходской совет Парижской Александро-Невской церкви назначил ему пенсию, ограничив её получение 1924 годом.). И только комитет французских евреев сделал рыцарский жест: преподнес русскому священнику прекрасную искусственную руку.

Вот почему отец Спасский объявлял:

- Мне ее подарили французские жиды!» (Парнах 2005, с. 54).

Итак, все сведения, которые сообщает нам Парнах, предельно точно соответствуют тому, что пишет и митрополит Евлогий (Георгиевский), и тому, что сообщает православный сайт. Мы даже можем разметить текст Парнаха ссылками на годы, когда происходили те или иные подвижки в жизни Соколовского, что мы сделали прямо в процитированном тексте.

И все-таки, 1924 г. в биографии Соколовского имеет для нас свое значение: «в знак протеста даже перестал носить рясу, хотя с апреля 1924 года проживал в приходском доме при церкви». Именно тогда о. Спасский-Соколовский и обратился с жалобой в Москву в «обновленческий» Священный Синод. Его письмо, адресованное на имя «митрополита» Евдокима (Мещерского), было (с сокращениями и без указания авторства) напечатано в первом номере обновленческого журнала «Христианин». В этом послании содержались многочисленные жалобы на митрополита Евлогия и выпады против русского духовенства во Франции» ${ }^{1}$.

Для того, чтобы понять, что это значило, когда священник без рясы живет в приходском доме и жалуется на зарубежников «обновленцам», надо просто сопоставить Постановление 2-го Всероссийского обновленческого поместного собора Русской православной церкви «Об отношении церкви к социальной революции, советской власти и патриарху Тихону» от 3 мая 1923 года с описанной ситуацией: «4. Священный собор призывает всех церковных людей бросить все попытки использовать церковь в земных политических расчетах. Церковь принадлежит Богу и ему единому служить должна. Контрреволюции в церкви не должно быть места. Советская власть не является гонительницей церкви. Согласно конституции советского государства, всем гражданам предоставляется подлинная религиозная свобода совести. Декрет об отделении церкви от государства обеспечивает эту свободу. Свобода религиозной пропаганды

\footnotetext{
1 Это важная деталь, т.к. в «Пансионе Мобэр» упоминаются некие клеветнические статьи «свящ. Спасского», на которые были ответы в парижской печати. 
(наряду со свободой пропаганды антирелигиозных идей) дает верующим возможность идейно отстаивать ценность своих чисто религиозных убеждений. Поэтому церковным людям нельзя видеть в советской власти власть антихристову: наоборот, Собор обращает внимание, что советская власть государственными методами одна во всем мире имеет [цель] осуществить идеалы Царства Божия. Поэтому каждый верующий церковник (Так! - Л.К.) не только должен быть честным гражданином, но и всемерно бороться вместе с советской властью за осуществление на земле идеалов Царства Божия» (Конфессиональная политика. $1 / 4442)$.

Тогда же, в разного рода посланиях обновленческий Синод осуждал сразу и Патриарха Тихона (Белавина) и зарубежную церковь, т.е. Евлогия (Георгиевского) в том числе. Вот, что означает фраза митрополита, будто о. Сергей Соколовский выступал в духе Поместного собора, естественно, обновленческого.

Разумеется, когда писались его мемуары, открыто осуждать мероприятия советской власти по отношению к РПЦ было невозможно. Ведь с 1945 года он уже был в РПЦ, а мемуары надиктовывались уже в самое последнее время, когда Сталин восстановил Патриаршество.

Но вот рассказ о ситуации в приходском доме в интересующее нас время из мемуаров Владыки: «В заседаниях обсуждали бесплодные вопросы. Товарищ Председателя граф В.Н.Коковцов отозвался о занятиях Совета не без иронии: «Наш Совет интересуют только два вопроса: о сторожах и о гробах». Сюда же надо присоединить споры, тянувшиеся месяцами, о выселении из церковного дома озлобленного, а потом запрещенного, бывшего военного протоиерея священника Соколовского, о регенте Огородникове, о псаломщиках... Сколько речей, пикировок, жарких прений по поводу мелочей! Вскоре я убедился, что в отношении духовной организации церковного народа на Совет рассчитывать нечего» (Евлогий).

Похоже, эта ситуация и привела о. Сергея Соколовского в «Пансион Мобэр».

Если же сопоставить сказанное с событиями в церкви, то между явной тягой к обновленчеству о. Сергея Соколовского еще в августе 1921 г. при первой встрече в Париже с митрополитом Евлогием, переездом священника в дом причта Александро-Невской Церкви, постановлениями обновленческого синода, решениями Антирелигиозной Комиссии (После установления дипломатических отношений между СССР и Францией в 1924 году представитель СССР обратился к французским властям с просьбой наложить арест на русскую церковную недвижимость во Франции, надеясь, что впоследствии, после судебного разбирательства, церковное имущество перейдёт во владение «обновленцев») 22 октября того года судом первой инстанции департамента Сены был наложен арест на имущество Русской Церкви во Франции. С этого времени выразителем интересов обновленцев во Франции стал Сергий Соколовский.

28 ноября 1924 года АРК приняла решение «поручить т. Тучкову принять через Синод меры к образованию во Франции обновленческих общин, используя для этого священника Соколовского, каковым постепенно производить передачу церкви». 
Борьба подобного рода велась до 1930 г., когда парижский суд, как уже говорилось, отклонил претензии советских обновленцев на имущество зарубежной Церкви, и в 1930 г. о. Соколовский вернулся в Москву.

Сейчас нам можно было бы предъявить претензии в том, что мы приписываем бедному, страдающему и почти нищему поэту В.Я. Парнаху, зарабатывающему собиранием рецензий на театр Мейерхольда или недорогими танцами собственного сочинения ${ }^{2}$, сотрудничество с советскими органами т.д., ведь деятельность о. Сергея Соколовского секретом не была, бесконечные суды вокруг «навашинского» банка и деятельности младшего брата виднейшего сотрудника Наркоминдела М.М. Литвинова, равно как и русской церковной собственности, секретом не были (Генис).

Между тем, сам В.Я. Парнах вернулся в СССР в 1931 г. вслед за о. Сергеем Соколовским и незадолго до возвращения тому священного сана в обновленческом Синоде.

Следовательно, сцена из главки «Пансиона Мобэр» «Возвращение» может быт датирована достаточно точно.

Вот она: «Однажды, по возвращении в Париж, я зашел в советское полпредство. В приемной вдруг.. (я глазам своим не поверил)... я увидел... отца Спасского во плоти.

Он был принят раньше меня крупным работником полпредства. Скоро я встретил отца Спасского в редакции парижской советской газеты, в советском банке и в советском торгпредстве. В редакции советской газеты, ораторствуя среди студентов Парижского университета, бывших белогвардейцев, он воскликнул:

-Попы! Черносотенцы!

При этих словах я на него взглянул («Да сам ты кто?» - мог бы я спросить). Он метнул на меня злобный взгляд. И с умилением заговорил о русской автокефальной церкви в Чехословакии. (Слово «автокефальной» он произнес медовым голосом.)

Это было в эпоху разделения церквей на «живую» и «мертвую».

Отец Спасский стал сторонником «живой» и неутомимо строил козни против сторонников «мертвой».

Он стал советским гражданином, по примеру своего покровителя графа Алексея Алексеевича и других бывших погромщиков. («Что вы хотите? Жить надо!»)

Отец Спасский трудился теперь в советском банке. По слухам, он заведовал там... карандашами» (Парнах 2005: 82).

${ }^{2}$ Недавно стал известен такой разговор Маяковского с Мандельштамом, записанный со слов последнего Н.И. Харджиевым: «Из Парижа приехал Парнах. Он очень бедствовал и Мандельштам просил Маяковского чем-нибудь Парнаху помочь. А Маяковский даже рассердился:

- Я не понимаю! Ведь у нас даже четвертый сорт дефицитный товар! Ведь его рвут на части!» (Горяева/Харджиев. С. 448). 
Юмор здесь может почувствовать только тот, кто узнает, что в «навашинском» банке о. Сергей Соколовский заведовал хозчастью (Генис 2012)! А уж в сравнении с мемуарами митрополита Евлогия сочетание «злобы» и «умильности» просто поражает. Ведь знать мемуаров Владыки Парнах не мог.

Таким образом, особых причин сомневаться, что В.Я. Парнах имел прямое отношение к проблемам, которые его еврейской происхождение и круг интересов не предусматривали, нет. При этом мы не знаем точно, что именно делал он в этой среде, и сейчас говорить об этом невозможно.

Однако странный образ некоей Дарьи, которая напрямую была связана со священником «Спасским», как известно, это подлинная фамилия одного их священников парижского храма, не имевшего отношения к ГПУ и обновленчеству, заставляет присмотреться к тем женским персонажам, которые мелькают тогда в Берлине и Париже ${ }^{3}$.

Именно так, в Берлине и Париже, ведь «Пансиона Мобэр» обнаружить в Париже не удалось, а вот в Берлине Парнах жил в «Пансионе Добэр».

Дело в том, что один очень интересный персонаж женского пола связывает двух наших героев Ильязда и Парнаха. И для начала связь между ними объясняется не столько чисто личными контактами, сколько областью интересов, отразившихся в их просоветской, но ненапечатанной прозе.

Если В.Я. Парнах, как мы видели, заинтересованно описывает о. Сергея Соколовского, который откровенно сражается с русской Зарубежной Церковью

3 Обратим внимание на отчество «Дарья Африкановна». Это не очень обычное имя. Исследователь истории Донского казачества и «Тихого Дона» 3. Бар-Селла обратил наше внимание на то, что последнего атамана Войска Донского звали Африка́н Петро́вич Богае́вский (27 декабря 1872 [8 января 1873], станица Каменская Донецкого округа - 21 октября 1934, Париж) русский военачальник, один из командиров Добровольческой армии и руководителей Белого движения на Юге России. Атаман Всевеликого Войска Донского. Дочери у него не было, однако зная точность сведений В.Я. Парнаха по нашим предыдущим работам, об отчестве «Дарьи» стоит задуматься. Оба сына вне подозрений: Богаевский Борис Африканович родился в г. СанктПетербург 19.09(1.10).1908 г. умер в г. Монморанси (Montmorency, департамент Валь-д’Уаз (Val-d'Oise - Долина Уазы), Франция). 1.01.1975 г. окончил Русскую гимназию в г. Париж (Paris, Франция), окончил Высшую техническую школу в г. Руан по специальности инженер-химик (1930 г.), окончил Зарубежные Высшие военно-научные курсы под руководством генерал-лейтенанта Н.Н. Головина в г. Париж (Франция), во время Второй мировой войны: 1939 г. - призван во французскую армию, курсант Артиллерийской аппликационной школы в г. Пуатье (Ecole d'Application d'Artillerie de Poitiers), пулемётчик отряда курсантов Артиллерийской аппликационной школы,ьранен и контужен при авиабомбардировке на реке Луара у г. Сомюр (Saumur, департамент Мен и Луара (Maine-et-Loire), Франция) 19.06.1940 г., оглох на левое ухо, председатель Казачьего союза во Франции, редактор журнала «Родимый край» (г. Париж, Франция) (с 1954 г.) награды: Военный крест 1939 - 1945 гг. с пальмовой ветвью.

Богаевский Евгений Африканович родился в г. Санкт-Петербург 23.06.1905 г. умер в г. Нью-Йорк (New York, США) 28.05.1977 г. капитан Королевской югославской армии окончил Донской императора Александра III кадетский корпус (1926 г.), учёба в Особой военной школе Сен-Сир (Ecole speciale militaire de Saint-Cyr) - ...1925 г. - ...1927 г. (112-й выпуск) во время Второй мировой войны: офицер 5-го кавалерийского королевы Марии полка - ...1927 г. ? - ...04.1941 г. - тяжело ранен, взят в плен, в заключении в лагере военнопленных - ...04.1941 г. - ...05.1945 г. http://samlib.ru/m/minaew_d_n/rus_emig_0_2.shtml Оба сына генерала воевали против Гитлера. 
под руководством ГПУ, то Ильяд подозрительно подробно знакомит читателя своей «Философии» с проблемами Братства Св. Софии, члены которого вовсе не стремились к открытости своих занятий и даже сторонились пронизанных агентами Советов евразийцев. Однако, как мы видим, им это не помогло.

Понятно, что советские органы не очень интересовались художественным отражением необходимых им материалов русской религиозной эмиграции. Однако такого рода тексты вполне могли использоваться в каких-то ситуациях в качестве информационного давления на своих противников, вызывая в кругах русской церковной эмиграции подозрительность и недоверие к своим же соратникам. Но случилось то, что случилось. И мемуарное сочинение В.Я. Парнаха, и роман «Философия» Ильязда в свет не вышли.

Между тем, достаточно давно стало ясно, что и «Философия», и «Пансион Мобэр» связаны не только и даже не столько своим конкретным содержанием, что и было бы просто странно, сколько странным же интересом в один и тот же период к очень близким церковным проблемам в Париже, в частности, и в русском зарубежье вообще, у двух столь разных людей ${ }^{4}$.

При этом сам Ильязд был очень далек от какой-либо веры и религиозности. Таким образом, два авангардиста, один - еврей, не связанный с иудаизмом, но националист и даже сионист (Кацис, Брусиловская 2018) и другой - полу-поляк, полу-грузин, идейный противник Российской Империи, чуть ли не русофоб, проявляют очень странный интерес к предельно русским и явно внутриправославным проблемам в эмиграции.

В свою очередь, в это самое время в Париже оказывается еще более важная фигура, связанная и с авангардисткими кругами, и, уже гарантированно, с советской разведкой, Елена Феррари

«В ноябре 1922 года Голубовская была назначена помощником С. П. Урицкого, нового резидента Разведупра и ОГПУ в Париже, после провала Якова Рудника. Своим берлинским знакомым она представила эту поездку как вызванную литературными интересами. Шкловский написал для направлявшейся в Париж Феррари, увлечённой авангардом, рекомендательное письмо футуристу Илье Зданевичу.

В конце 1922 - начале 1923 года Феррари стала активным участником собраний Берлинского дома искусств, и её имя неоднократно упоминается в прессе. Тесно общается с художником Иваном Пуни, жившим неподалёку от неё в Берлине. Их соседство упоминается в повести Шкловского «Zoo, или Письма не о любви», где имеется и словесный портрет Елены: «У неё лицо фарфоровое, а ресницы оттягивают веки. Она может ими хлопать, как дверьми несгораемых шкафов...». Феррари выступала в Берлине также совместно с ита-

${ }^{4}$ А к ним еще можно прибавить и М.А. Булгакова с «Мастером и Маргаритой», где т.н. «Евангелие от Михаила» или «От Воланда» не так уж и самостоятельно, равно как и роман К. Малапарте «Бал в Кремле» (Малапарте), где Булгаков оказывается героем романа, которому мы посвятили специальную работу именно в этом аспекте. Не сомневаемся, что это далеко не все. Ср. (Кацис 2020 в печати). 2017).

${ }^{5}$ В полемике с нами ее называет и публикатор «Философии» С.В. Кудрявцев (Кацис 2016- 
льянским футуристом Руджеро Вазари. В 1923 году в Берлине (издательство «Огоньки») выходит сборник стихотворений Феррари «Эрифилли» (название - греческое женское имя, буквально «горячо любимая»). Планировались к выходу (в издаваемом Горьким журнале «Беседа» и отдельной книгой) её прозаические «сказки», которые, в отличие от стихов, Горькому нравились, однако публикация не состоялась.

В апреле 1923 года Горький выясняет (по-видимому, через своего сына Максима Пешкова, имевшего личные знакомства в ОГПУ) её прошлое и предупреждает Ходасевича, чтоб тот был осторожнее с Феррари: «на большевичков работает, служила у них в контрразведке... она протаранила в Константинополе белогвардейскую яхту». Сохранилось письмо поэтессы к Горькому от 22 апреля 1923 года, где она сокрушается по поводу каких-то слов Максима Пешкова и ходящих вокруг её биографии слухов, не говоря ничего определённого. Через два дня Горький отвечал, что Феррари, рассказывая о своей биографии, «говорит о себе неверно», но «говоря о себе, ничего не ищет, кроме себя». (https://ru.wikipedia.org/wiki/Елена_Феррари).

С 1923 г. Феррари оказывается в Москве, затем - в Италии, где выходит ее очередной «константинопольский» сборник «Prinkipo». И, наконец, самое интересное для нас и поразительно совпадающее со многими датами в жизни В.Я. Парнаха: «В 1925 году Голубева (Голубовская) вернулась в СССР и возобновила работу в аппарате Разведупра на месте. В январе 1926 года назначена сотрудником-литератором третьей части третьего отдела Разведупра РККА, но летом того же года уволена со службы. Печаталась под псевдонимами как журналист в советских изданиях («Новый зритель», «Красная нива», «Красная звезда», «Известия», «Юный коммунист», «Пионер»), а также продолжала публиковаться в Италии. В 1926-1930 годах не работала в разведке, находясь, однако, в резерве РККА, затем вновь получила задание во Франции и работала там помощником резидента, пользуясь прежним псевдонимом Феррари. В 1932 году на страницах парижской газеты «Возрождение» Н. Н. Чебышёв, сотрудник врангелевской контрразведки, со слов Ходасевича предаёт гласности участие Елены Феррари в таране яхты «Лукулл», назвав, помимо псевдонима, также фамилию «Голубева» (героиня заметки в то время вновь находилась во Франции, что, возможно, стало известно Чебышёву) и особую примету - отсутствие пальца на руке. В начале 1933 года разведчица была отозвана в Москву, либо из-за статьи Чебышёва, либо из-за серии провалов советской агентуры в Европе.

Постановлением ЦИК СССР от 21 февраля 1933 года Ольга Голубева награждена орденом Красного Знамени «за исключительные подвиги, личное геройство и мужество» (орден вручён 7 июля 1933 года)» (https://ru.wikipedia.org/ wiki/Елена_Феррари), (ср. Лота 2020).

То, что в этой справке названо «серией провалов советской агентуры» - это окончание эпидемии «перебежничества». Правда, здесь надо быть осторожным, многие «перебежчики» тоже делали это по заданию. Отметим, что Феррари не только просто общалась с авангардистами, но открыто печатала стихи с посвящениями Ивану Пуни или Ксении Богуславской, писала стихи об анархистском отряде им. Бакунина, в котором она была вместе со своим мужем Голубевым, где цитировала Интернационал. 
Однако, в любом случае, Парнах вернулся в СССР летом 1931 г. и больше за границей не был. Феррари же вернулась в СССР в 1933, хотя ей еще довелось поработать за границей, но ведь она была штатным профессионалом.

И вот как раз в период пребывания интересующих нас лиц в Париже, в советской Москве выходят в свет произведения О.Э. Мандельштама «Шум времени» и «Египетская марка». Если первая книга может и должна быть поставлена в параллель будущей русско-еврейской автобиографии Парнаха, то во второй книге молва сразу же увидела автора тогда никому не известного «Пансиона Мобэр» - Валентина Парнаха. И в какой-то момент возникла легенда о том, что Парнах был невероятно оскорблен поступком друга и т.д.

Разумеется, Парнах никогда не был т.н. «маленьким человеком» русской литературы, а Мандельштам вовсе не сразу назвал своего героя этим искаженным именем своего соседа. Есть в черновиках «Египетской марки» и прямое упоминание Парнаха (Кацис, Брусиловская 2018), и имя героя одного из вариантов было Валентин, и т.д. Поэтому надо еще подумать, что заставило советского поэта писать исключительно плотную прозу, открыто упоминая достаточно узнаваемого всеми, кому это важно, поэта-эмигранта? К кому была обращена «Египетская марка», само действие которой аккуратно избегало именно тех моментов, когда реальный Парнах был в России. Либо, наоборот, рассуждая о едущих на отдых после тяжелой дневной работы колесных пирамидах на ночных ленинградских улицах, Мандельштам вдруг заявлял, что «не Анатоля Франса хороним», напоминая о Франции, куда чуть позже и отправится Парнах. Но ведь скажет он это не в 1924 г., а в конце 1920-х.

Мог ли О.Э. Мандельштам играть в подобные игры? Знал ли он не всегда открытые непосвященным цели поездок откровенного еврея-русофоба, которого в России привлекал только язык русской поэзии, в русский православный Париж?

Сейчас мы не можем ответить на эти вопросы. Однако был в жизни и творчестве О.Э. Мандельштама один эпизод, который может указать нам путь последующих поисков. И связан он с двумя моментами. Первый, это исключение из «Шума времени» главок типа сохранившегося в архиве Мандельштама «Возвращения» из Грузии, которое Мандельштам велел выбросить из текста воспоминаний, чтобы не было прямой связи между «Феодосией» и Батумом. Ведь и там, и там Мандельштам арестовывался контрразведкой, и оттуда, и оттуда приходилось бежать. Сейчас мы не будем касаться этого специально, но в обоих случаях Мандельштам, по сведениям Н.Я. Мандельштам, вывозил «бумаги», связанные с просоветскими восстаниями в Крыму и Грузии (Мандельштам Н. 2014).

Наконец, существовали две главки «Египетской марки», которые мы до сих пор не знаем: «Встреча в редакции» и «Авессалом», которые упомянуты лишь в письме редактору А. Коробовой от 25 июня 1928 г. из Ялты (Мандельштам- Коробовой).

Тон, которым написано письмо, а также содержан6ние известных нам «Меньшевиков в Грузии» и «Возвращения» заставляет думать, что и выброшенные из «Египетской марки» главки могли волновать Мандельштама не из литературных соображений. 
Не зная этого текста, но зная, что одна из главок должна была называться «Авессалом», с учетом содержания соотвествующего Псалма и сюжета Книги Царств, связанного с этим именем, можем предположить, что здесь нашли отражение те сионистские мотивы биографии Парнаха, которые позже отразились в «Пансионе Мобэр». В 1928 г. подобная тематика была очень остра и в связи с активностью сионистов в Польше, и в связи с выходом в свет по-русски мемуаров В.Е. Жаботинского о Еврейском Легионе, и т.д.

Создается ощущение, что сама идея печатать в Советском Союзе повесть о революции с главным героем, находящемся в момент публикации то ли в эмиграции, то ли по заданию за границей, имела некий смысл, выходящий за литературные пределы. В самом простом смысле - это попытка представить вполне серьезного человека Валентина Парнаха неким ничтожным и мелким «Башмачкиным». А «Башмачкин» в это время как раз общался в Париже с посетителями советского представительства, «навашинского» банка, разбирался в непростых взаимоотношениях внутри расколотой русской Церкви, а также узнавал в Большом театре в качестве коммунистов и чекистов своих бывших парижских знакомых, легко сменивших вехи, либо, как Феррари, в очередной раз готовились к возвращению на оперативную работу.

Нам уже приходилось писать о том, что никаких обид из уст Парнаха на «Египетскую марку» никто напрямую не слышал. Более того, уже во время Второй мировой войны в Чистополе он вспоминал Мандельштама безо всякого раздражения, вспоминая, что тот называл его моим «alter ego». И уже нам приходилось показывать, что проза и другие тексты Парнаха полны откликов на очень поздние и не всегда напечатанные своевременно стихи Мандельштама.

Да и люди, знавшие Парнаха по Парижу, не очень верили в Парнока-Парнаха. Вот яркие страницы А. Бахраха: «...выбор Мандельштамом для своего героя весьма причудливой фамилии породил гипотезу (в частности, пущенную в научный обиход ученейшим Глебом Струве, а затем и американским исследователем поэзии Мандельштама Кларенсом Брауном, опиравшимся на анонимные и не вполне достоверные источники), что прототипом Парнока послужил поэт Валентин Парнах, подписывающийся иногда Парнак или даже Парнок.(...)

Этого Парнаха в самом начале двадцатых годов, на самой заре эмиграции, я не раз встречал в Париже. Вместе с Божневым и Гингером он был одним из столпов «Палаты поэтом», вероятно, первого зарубежного содружества, созданного в те дни, когда русских поэтов в Париже можно было перечислить по пальцам.(...)»

И далее, перепутав годы выхода в свет книги о еврейских поэтах-жертвах испанской инквизиции, продолжал: «Парнах возвратился в Советский Союз, по его словам, для пропаганды джаза, который в Москве тогда был еще невидалью. Удалась ли ему карьера эстрадного эксцентрика, о которой он мечтал, мне неизвестно. Знаю только, что в конце 20-х годов в еще не вполне скомпрометированном покровительством Каменева издательстве «Академиа» вышел переведенный им им с испанского томик стихов под заманчивым заглавием «Поэты - жертвы инквизиции». Знаю еще, что несколькими годами позже он времен- 
но появился на берегах Сены, опубликовал кое-какие статьи во французских журналах, а когда Мейерхольд приехал показывать Парижу своего «Ревизора», Парнаха ежевечерне можно было видеть в фойе театра - его присутствие не вызывалось причастностью к мейерхольдовской труппе, а ухаживанием за одной из ее участниц. (Недаром Мандельштам писал, что его Парнок был «жертвой заранее созданных концепций о том, как должен протекать роман»!). Слышал также, что в одном почтенном еврейско- американском толстом журнале тогда же появилась статья Парнаха о роли евреев в русской литературе. Можно только удивляться, что после такого длинного списка «прегрешений», вернушись в Москву, он прожил там все черные годы «безболезненно».(...)

А все же. Какое-то сомнение или тень сомнения невольно рождается, хоть между Парноком и Парнахом нет ни литературного, ни, главное, духовного сходства. Ведь все-таки, может быть, Мандельштам вспомнил о своем парижском собутыльнике (может быть, он в те годы встречал его и в Москве) и както очень по-своему свой рассказ транспонировал, чтобы «замести следы» и тем Парнаха увековечить. Бывают случаи, когда заманчиво не ставить никаких точек над «і»» (Бахрах 2020).

Эти сомнения очень стоит принять во внимание. Но сейчас мы остановимся на сказанном.

Разумеется, предложенный подход к взаимоотношениям трех названных тут поэтов не совсем привычен. Однако основан он на тех сведениях, которые в прежнее время во внимание не принимались, а теперь мы, узнав священника «Спасского», уже не можем не принимать их во внимание. И это то, что дало нам исследование чисто эмигрантского либо внесоветского контекста биографий трех больших русских поэтов. А ненапечатанные (и пока нам не известные) главки «Египетской марки» сделали ее, если не неопубликованной, как «Философия» или «Пансион Мобэр», то, по крайней мере, неопубликованной полностью, как, кстати, и «Шум времени». И это неожиданно ставит прозу О.Э. Мандельштама в намеченный здесь ряд.

\section{Использованная литература}

Бахрах, Александр В. По памяти, по записям. <https://www.rulit.me/books/literaturnyeportrety-po-pamyati-po-zapisyam-read-217238- 65.html $>$ 12.06.2020.

Генис, Владимир Л. Неверные слуги режима. Первые советские невозвращенцы (1920-1933). Кн. 2. «Третья эмиграция» (1929-1933). Москва: Б.и., 2012.

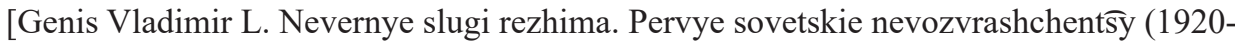
1933). Kn. 2. «Tret'iāemigratșiā» (1929-1933). Moskva: B.i., 2012]

Горяева, Татьяна М. «Н.И. Харджиев и В.В. Маяковский». [В:] Архив Н.И. Харджиева. Русский авангард: материалы и документы из собрания РГАЛИ. Т. III. Москва: Издательство «ООО ДЕФИ», 2019, 410-456.

[Goriāeva Tatiana M. N.I. Xardzhiev i V.V. Maiakovskiǔ [In:] Arkhiv N.I. Xardzhieva. Russkiı̌ avangard: materialy i dokumenty iz sobraniia RGALI. T. III. Moskva: Izdatel'stvo «OOO DEFI», 2019, 410-456]

Евлогий (Георгиевский), митр. Путь моей жизни, гл. 20 «Архиепископ - митрополит Православной Русской Церкви в Западной Европе» <http://pravbeseda.ru/ 
library/index.php?page $=$ book\&id $=740>12.06 .2020$.

[Evlogiǔ (Georgievskǐ̌), mitr. Put' moê̌ zhizni, gl. 20 «Arkhiepiskop - mitropolit Pravoslavnoй Russkoĭ TSerkvi v Zapadnoĭ Evrope»<http://pravbeseda.ru/library/ index.php?page=book $>12.06 .2020$.

Зданевич, Илья М. (Ильязд). Философия футуриста: Романы и заумные драмы. Предисл. Р. Гейро; подг. текста и комм. Р. Гейро и С. Кудрявцева. Москва: Гилея, 2008.

[Zdanevich Il'iā M. (Il'iâzd). Filosofiiâ futurista: Romany i zaumnye dramy. Predisl. R. Geřro; podg. teksta i komm. R. Geĭro i S. Kudriâvtševa. Moskva: Gileiā, 2008]

Кацис, Леонид Ф. Роман Ильи Зданевича «Философия» как Философия (А. В. Карташев, о. Сергий Булгаков, А. Ф. Лосев и др.). [В:] Исследования по истории русской мысли. Ежегодник. [10]: Ежегодник за 2010-2011 год. Москва: Модест Колеров, 2014, 363-403.

[Katsึis Leonid F. Roman Il'i Zdanevicha «Filosofiiā» kak Filosofiiā (A. V. Kartashev, o. Sergiı̌ Bulgakov, A. F. Losev i dr.). [In:] Issledovaniiâ po istorii russkoĭ mysli. Ezhegodnik. [10]: Ezhegodnik za 2010-2011 god. Moskva: Modest Kolerov, 2014, 363-403]

Кацис, Леонид Ф. Заметки читателя историко-(анти) философской литературы IV. Илья Зданевич, «Философия») и анти-философия С.В. Кудрявцева. [В:] Исследования по истории русской мысли Ежегодник. [13]. Ежегодник 20162017. Москва: Модест Колеров, 2017, 901-920.

[Katșis, Leonid F. Zametki chitateliā istoriko-(anti) filosofskoî literatury IV. Il'iā Zdanevich, «Filosofiiā») i anti-filosofiiā S.V. Kudriâttseva [In:] Issledovaniiā po istorii russkoř mysli Ezhegodnik. [13]. Ezhegodnik 2016-2017. Moskva: Modest Kolerov, 2017, 901-920]

Кацис, Леонид Ф. Почему «Египетская марка» О. Мандельштама «египетская» и почему «марка»? К проблеме построения не филателистического литературоведения на текстах о 1917-1918 гг. [В:] Исследования по истории русской мысли. Ежегодник. [14]. Ежегодник за 2018 год. Москва: Модест Колеров, 2018, 640 750 .

[Katșis Leonid F. Pochemu «Egipetskaiā marka» O. Mandel'shtama «egipetskaiā» i pochemu «marka»? K probleme postroeniiā ne filatelisticheskogo literaturovedeniiā na tekstakh o 1917-1918 gg. [In:] Issledovaniiā po istorii russkoĭ mysli. Ezhegodnik. [14]. Ezhegodnik za 2018 god. Moskva: Modest Kolerov, 2018, 640-750]

Кацис, Леонид Ф. Заметки читателя историко-философской литературы. V-VI. Митрополит Евлогий и «Пансион Мобэр». [В:] Исследования по истории русской мысли. Ежегодник. [10]: Ежегодник за 2010-2011 год. Москва: Модест Колеров, 2018, 626-656.

[Kațึis L. Zametki chitateliâ istoriko-filosofskoî literatury. V-VI.Mitropolit Evlogiū i «Pansion Mobèr» [In:] Issledovaniiā po istorii russkoî mysli. Ezhegodnik. [10]: Ezhegodnik za 2010-2011 god. Moskva: Modest Kolerov, 2018, 626-656]

Кацис, Леонид Ф. «Бал в Кремле» Курцио Малапарте: опыт обратного перевода на язык «Мастера и Маргариты». [В:] Русский сборник. Исследования по истории России. Т. XXIX. Москва: Модест Колеров, 2020 (в печати).

[Katșis Leonid F. «Bal v Kremle» Kurtșio Malaparte: opyt obratnogo perevoda na iâzyk «Mastera i Modest Margarity». [In:] Russkiı̆ sbornik. Issledovaniiā po istorii Rossii. T. XXIX. Moskva: Kolerov. 2020 (v pechati)] 
Кацис, Леонид Ф., Лилия Б. Брусиловская. «К французской речи» или Если Парнок - не В. Парнах? «Пансион Мобэр» и О. Мандельштам [В:] Русский сборник. Исследования по истории России. XXIV. Московия в свидетельствах иноземцев. Москва: Модест Колеров 2018, 569-625.

[Katșis, Leonid F., Liliā B. Brusilovskaiā. «K franţิuzskoĭ rechi» ili Esli Parnok - ne V. Parnakh? «Pansion Mobèr» i O. Mandel'shtam [In:] Russkiı̌ sbornik. Issledovaniiā po istorii Rossii.XXIV. Moskoviiâ v svidetel'stvakh inozemtšev. Moskva: Modest Kolerov, 2018, 569-625]

Конфессиональная политика советского государства. 1917-1991. Документы и материалы. Т. 1. Кн. 4. Религиозные объединения, духовенство и верующие, общественные организации и граждане о вероисповедной политике советского государства и религиозной ситуации в стране. Москва: РОССПЭН, 2018.

[Konfessional'naiā politika sovetskogo gosudarstva. 1917-1991. Dokumenty i materialy. T. 1. Kn. 4. Religioznye ob"edineniiā, dukhovenstvo i veruiưshchie, obshchestvennye organizatșii i grazhdane o veroispovednoî politike sovetskogo gosudarstva i religioznor̆ situatsii v strane. Moskva: ROSSPE்N, 2018]

Ливак, Леонид, Андрей Б. Устинов. «Литературный авангард русского Парижа». 1920-1926. История. Хроника. Антология. Документы. Москва: ОГИ, 2014.

[Livak Leonid, Andrei B. Ustinov. "Literaturnyı̌ avangard russkogo Parizha". 19201926. Istoriiâ. Xronika. Antologiiâ. Dokumenty. Moskva: OGI, 2014]

Лота, Владимир И. Елена Феррари - резидент “особого калибра”. Поэтесса, разведчица или террорист? Москва: Изд. Дом Комсомольская правда, 2020.

[Lota Vadimir I. Elena Ferrari - rezident “osobogo kalibra”. Poètessa, razvedchitsa ili terrorist? Moskva: Izd. Dom Komsomol'skaiā pravda. 2020]

Свящ. Мазырин, Александр В., Андрей А. Кострюков. Из истории взаимоотношений русской и константинопольской церквей в XX веке. Москва: СвятоТихоновский Православный гуманитарный университет, 2017.

[Sviāshch. Mazyrin, Aleksandr V., Andrei A. Kostriukov. Iz istorii vzaimootnosheniū russkoř i konstantinopol'skoĭ tšrerkveǐ v XX veke. Moskva: Sviäto-Tikhonovskiĭ Pravoslavnyı̆ gumanitarnyı̆ universitet, 2017]

Малапарте, Курцио. Бал в Кремле [незаконченный роман]. Пер. с итал. А.В. Ямпольской. Науч. ред. М.П. Одесского. Вст. ст. М.П. Одесского, Н.А. Громовой, С. Гардзонио. Комм. М.П. Одесского, Н.А. Громовой. Москва: Издательство АСТ: Редакция Елены Шубиной, 2019.

[Malaparte, Kurcio. Bal v Kremle [nezakonchennyı̆ roman]. Per. s ital. A.V. IÄmpol'skoŭ. Nauch. red. M.P. Odesskogo. Vst.st. M.P. Odesskogo, N.A. Gromovoŭ, S. Gardzonio. Komm. M.P. Odesskogo, N.A. Gromovoř. Moskva: Izdatel'stvo AST: Redakt siiā Eleny SHubinoĭ, 2019]

Мандельштам, Надежда. Биографическая канва. [В:] Мандельштам Н. Собр. соч.: В 2 т. Т. 2: «Вторая книга» и др. произведения (1967-1979). Сост. С. В. Василенко, П. М. Нерлер, Ю. Л. Фрейдин, подгот. текста С. В. Василенко при участии П. М. Нерлера и Ю. Л. Фрейдина, коммент. С. В. Василенко и П. М. Нерлера. Екатеринбург: ГОНЗО, 2014.

[Mandel'shtam, Nadezhda. Biograficheskaiā kanva. [In:] Mandel'shtam N. Sobr. soch.: V 2 t. T. 2: «Vtoraiā kniga» i dr. proizvedeniiā(1967-1979). Sost. S. V. Vasilenko, P. M. Nerler, IU. L. Freǐdin, podgot. teksta S. V. Vasilenko pri uchastii P. M. Nerlera i IU. L. Freĭdina, komment. S. V. Vasilenko i P. M. Nerlera. Ekaterinburg: GONZO, 2014] 
Мандельштам, Осип. «Коробовой Анне». 25.06.1928. [В:] Мандельштам Осип. Полн. собр. соч. в 3-х т. Т. 3. Проза. Письма. Санкт-Петербург: Изд. Дом «Гиперион», 2017, 385-386.

[Mandel'shtam, Osip. «Korobovoĭ Anne». 25.06.1928. [In:] Mandel'shtam Osip. Poln. sobr. soch. v 3-kh t. T. 3. Proza. Pis'ma. Sankt-Peterburg: Izd. Dom «Giperion», 2017, 385-386]

Парнах, Валентин. Пансион Мобэр. Воспоминания. Вступительная статья П.Нерлера. Публикация и комментарии П.Нерлера и А.Парнаха. Подготовка текста П.Нерлера, Н.Поболя и О. Шамфаровой. [В:] Диаспора VII. Новые материалы. Париж - Санкт-Петербург: Athenaeum - Феникс, 2005, 8-91.

[Parnakh. Valentin. Pansion Mobèr. Vospominaniiā. Vstupitel'naiā stat'iā P.Nerlera. Publikatsiia i kommentarii P.Nerlera i A.Parnakha. Podgotovka teksta P.Nerlera, N.Poboliā i O. Shamfarovoř. [In:] Diaspora VII. Novye materialy. Parizh - SanktPeterburg: Athenaeum - Feniks, 2005, 8-91]

Леонид Ф. Кацис

\author{
В. ПАРНАХ, И. ЗДАЬЕВИЧ И „ПАЛАТА ПЕСНИКА“: \\ ИЗМЕЪУ КЬИЖЕВНОСТИ, НКВД-а, „ЕГИПАТСКЕ МАРКЕ“ \\ И „ШУМА ВРЕМЕНА“ О. МАНДЕЉШТАМА
}

\title{
Резиме
}

Чланак је посвећен упоредној анализи прозних текстова трију руских песника Осипа
Мандељштама, Иљазда (,Филозофија“) и Валентина Парнаха („Пансион Мобер”) са једног
неуобичајеног становишта. Један од њих („Филозофија“ Иље Здањевича) написан је у
емиграцији и био намењен објављивању у Совјетском Савезу; други („Пансион Мобер“ В.
Парнаха) писао је аутор који је повремено живео у Берлину, Паризу и Совјетском Савезу и
никада га није довршио; трећи („Шум времена“ О. Мандељштама) написан је и објављен у
СССР. Текст крајњег авангардисте-заумника Иљазда, неочекивано нимало зауман, дотиче се
не само околности почетка руске емиграције у Константинопољ, већ одсликава и тајну делат-
ност антисовјетског „Братства Св. Софије“. Успомене Валентина Парнаха, које у низу аспека-
та руско-јеврејског саставног елемента биографије мемоаристе подсећају на „Шум времена”
О. Мандељштама, рефлектовале су веома сложена збивања у вези са покушајима совјетске
власти да преузме иницијативу у емигрантским црквеним размирицама кроз инфилтрирање
представника тзв. Обновљенске цркве. Као и у првом случају, који се односи на наизглед
немогућу активност тог типа за авангардисту-заумника левичарских погледа, тако и у другом,
када је реч о Јеврејину, који себе назива чак и русофобом, испада да су обојица повезани са
њима засигурно туђим круговима беле руске и црквене емиграције, што наводи на тражење
везе између таквих збивања. У случају В. Парнаха и Иљазда њу је лако пронаћи, будући да су
обојица били оснивачи тзв. „Палате песника“у Паризу. Што се тиче О. Мандељштама, на ос-
нову претходних ауторских истраживања познато нам је да лична биографија Парнаха ни по
чему не наликује биографији његовог двојника - „човечуљка“ Парнока, који је постао јунак
„ггпатске марке“. Штавише, сви догађаји у Мандељштамовој прози одигравају се у Русији
управо у време када тамо засигурно није био присутан В. Парнах. Притом је име главног
јунака, на које се могло наићи у издавачким уговорима, било другачије - Валентин Горков,
где су се овом приликом поклапала имена Парнаха и Горкова“. Осим тога, О. Мандељштам је
имао биографске везе са обојицом јунака из чланка, док је В. Парнах део свог времена, про- 
веденог у Москви, боравио у стану аутора „Египатске марке“. Као што је познато из наших претходних радова, В. Парнах и Иљазд су укључили у своја дела податке, који су били недоступни истраживачима претходних деценија и тек данас избијају на видело. То су такође и материјали „Братства Св. Софије“, и црквене размирице у Паризу двадесетих година око просовјетских „обновљенаца“, Руске православне цркве и круга митрополита Евлогија, који је нагињао ка Константинопољској патријаршији. Притом, као и у случају „Парнок”„Парнах”, где је О. Мандељштам искористио „званично” презиме Парнаха и његове сестре - песникиње Софије Парнок, аутор „Пансиона Мобер” је препознатљиво шифровао совјетског агента свештеника Соколовског именом стварног свештеника Спаског. Са своје стране, у роману „Филозофија” Иљазд је користио не само емигрантске, већ и неке не баш најдоступније податке о совјетској политици око Константинопоља средином двадесетих година. Представљени материјали омогућавају аутору да одмах постави питање: због чега је и у ком контексту О. Мандељштам учинио главним јунаком „Египатске марке” Парнака, са очигледном асоцијацијом на В. Парнаха, који се у то време налазио у Паризу у недефинисаном статусу било емигранта, било совјетског апатрида, било могућег шпијуна. Најзад, може ли се пронаћи веза између активности совјетске агентуре у Паризу, нарочито Ј. Ферари, непосредно укљученој у авангардне кругове Москве, Берлина и Париза и овде споменутих аутора. На крају чланка гради се претпоставка о томе да сам избор имена јунака „Египатске марке” може бити у вези са потребом формирања лика „малог човека” Валентина Парнаха, који је у стварном животу био далеко од тог типичног гогољевског јунака руске књижевности XIX века, већ је, попут Иљазда, био повезан са озбиљним совјетским структурама, које су занимале овде наведене специфичности духовног и политичког живота руске емиграције.

Кључне речи: Руска емиграција, Париз, „Шум времена“, „Египатска марка“, „Пансион Мобер“, НКВД. 